\title{
Comparison of Arnett's Soft Tissue Norms of Himachali Male Populationwith South Indianmale Population Using Digital Tracing Method: A Cephalometric Study
}

\author{
Upadhyay Sachin ${ }^{1}$, Sharma Aseem², Yatharth Goel ${ }^{3}$, Neelam Chauhan ${ }^{4}$, Phor Deepak ${ }^{5}$, Didhra Gaurav ${ }^{6}$ \\ ${ }^{1,2}$ Sr.Lecturer Department of Orthodontics and Dentofacial Orthopaedics, Himachal Institute of Dental Sciences, Paonta Sahib, Himachal Pradesh, India \\ ${ }^{3}$ Director at Dantam Dental Solutions 44, Civil Lines, Jadugar Road Roorkee Uttarakhand India \\ ${ }^{4}$ Consultant Orthodontist at Kullu Smiles Kullu Himachal Pradesh India \\ ${ }^{5} \mathrm{Sr}$, Lecturer Department of Orthodontics and Dentofacial Orthopaedics, Yamuna Dental College, Yamunanagar, Haryana, India \\ ${ }^{6}$ M.D.S. Department of Periodontics and Implantology Director at Dent-o-care Mehatpur, UNA Himachal Pradesh India
}

DOI: 10.36348/SJODR.2019.v04i09.018

| Received: 11.09.2019| Accepted: 20.09.2019| Published: 30.09.2019

*Corresponding author: Dr. Aseem Sharma

\section{Abstract}

Background: This analysis was developed directly from the philosophy expressed in Arnett and Bergman "Facial keys to orthodontic diagnosis and treatment planning, Parts I and II". The novelty of this approach, as with the "Facial Keys" articles, is an emphasis on soft tissue facial measurement. This article describes comparison of various facial lengths between Himachali male population and South Indian male population that contribute to an aesthetically pleasing face which should be considered during orthodontic treatment. The aim of the present study was to highlightthe differences in facial length norms between Himachalimales and South Indianmales. Materials and Methods: Lateral cephalograms of 50Himachali males of age group 18-25 years were taken in Department of Orthodontics, Himachal Institute of Dental Sciences, Paonta Sahib and tracing of soft tissue profile as well as related osseous and dental structures were made using Nemoceph software. Then Arnett's soft tissue traits were compared with Himachali traits. Results: The present study showed that there is decreasedupper lip length in Himachali males as compared to South Indian population. Conclusion: Individual norms are necessary for a population in order to plan and deliver quality treatment.

Keywords: Himachali males, South Indian males, soft tissue traits, treatment planning.

Copyright @ 2019: This is an open-access article distributed under the terms of the Creative Commons Attribution license which permits unrestricted use, distribution, and reproduction in any medium for non-commercial use (NonCommercial, or CC-BY-NC) provided the original author and source are credited.

\section{INTRODUCTION}

Preservation of facial attractiveness is an importantgoal of orthodontic treatment. Treatment planning requires knowledge of the parameters and normative data that helps to establish goals and predict the obstacles that need to be negotiated. Due to a complicated interaction of genetic and environmental factors the morphological features of an individual vary from race to race. Even within the same race, each subgroup had its own standards. Hence, the established norms for other ethnic group can not apply to the population of Himachal Pradesh. Therefore, the applicability of various soft tissue parameters proposed by Bergman, should be analyzed which will improve treatment planning for male population of Himachal Pradesh [1]. As Soft tissue norms serve as a guideline in calculating change it has been suggested that certain cephalometric standards relating teeth to cranial or facial bones could ensure good facial form if adhered to as a treatment goal [2].The attainment of facial soft- tissue proportionality is one of the principal goals in the treatment of dentofacial deformities and can be achieved with properly planned and executed orthognathic surgery techniques [3].Therefore the aim of this study is to compare the norms for themale population of Himachal Pradesh with the South Indianmale population so that the facial length cephalometric values of various parameters could be differentiated so as to guide the orthodontist towards a better diagnosis and treatment planning of dentofacial deformities for the population of Himachal Pradesh.

\section{MATERIALS AND METHODS}

This study was carried out in the Department of Orthodontics and Dentofacial Orthopaedics of Himachal Institute of Dental Sciences, Paonta Sahib (H.P). 50 Males in the age group of 18-25 years who were residents of Himachal Pradesh were considered for the study. All subjects were examined by a panel of the faculty members of the Department of Orthodontics 
and Dentofacial Orthopaedics and reasonably balanced faces were selected.Small diameters silver beads of dimension $2 \mathrm{~mm}$ (approx.) were chosen for the use as metallic markers.

All the cephalograms of patients were taken in natural head position with Carestream X-ray machine with model no CS8100 (2016). All the radiographs were traced using (Nemoceph) Dental Studio NX (2006) software after the calibration of the images.

All the landmarks were marked manually using inbuilt autozoom feature of the software and the measurement of the values and was done automatically by the Nemoceph software. Ten radiographs were also retraced after one week to check the intra-operator reliability. The Arnett's soft tissue cephalometric analysis (STCA)[4]was performed considering:

\section{Facial lengths}

Facial heights (Nasion'[Na] to Menton'[Me'])

Upper lip length (upper lip inferior [ULI] to subnasale[Sn])

Interlabial gap (ILG)

Lower lip length (lower lip superior [LLS] to Menton'[Me])

Lower $1 / 3$ of face (Subnasale[Sn] to Menton'[Me])

Overbite (OB)

Maxillary incisor tip (Mx1) exposure

Maxillary height (Subnasale [Sn] to tip of maxillary incisor tip[Mx1])

Mandibular height (Menton [Me]' to tip of mandibular incisor tip [Md1])

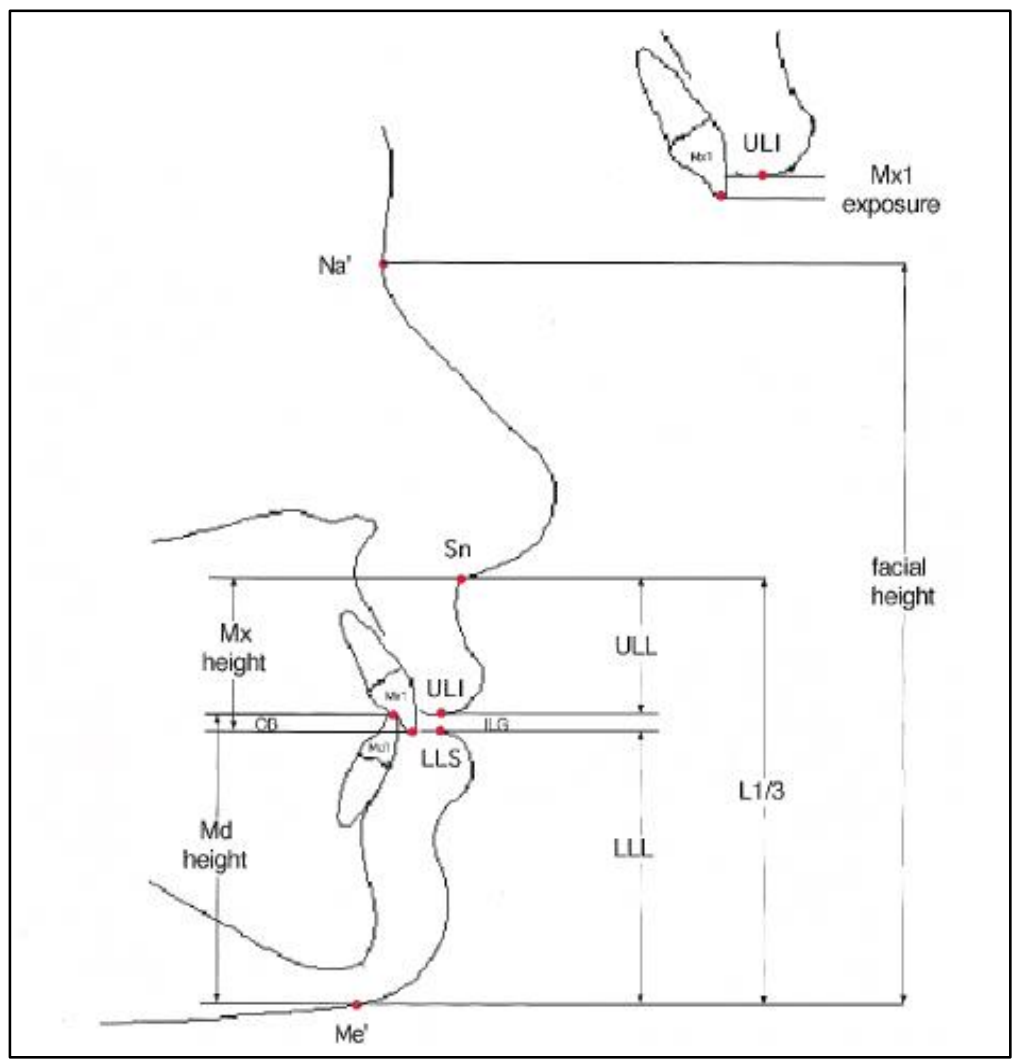

Fig-3: Facial heights / lengths

Values of all parameters thus obtained were organized in the form of a master chart using Microsoft Excel and were statistically analyzed and compared with South Indian male population.

\section{OBSERVATIONS AND RESULTS}

Comparison of Himachali males with South Indian value males shows that there are significant differences in values for Himachali ethnic male population and South Indian male population.
In the facial length measurements the values for upper lip length, interlabial gap, upper incisor exposure to relaxed lip, lower $1 / 3^{\text {rd }}$ height, maxillary height and mandibular height were $20.73 \pm 2.52 \mathrm{~mm}$, $1.42 \pm 0.82 \mathrm{~mm}, 3.00 \pm 1.39 \mathrm{~mm}, 69.20 \pm 5.11 \mathrm{~mm}$, $23.74 \pm 2.57 \mathrm{~mm}$ and $40.29 \pm 3.72 \mathrm{~mm}$ respectively for Himachali males and $22.33 \pm 3.57 \mathrm{~mm}, 0.15 \pm 0.48$ $\mathrm{mm}, 0.15 \pm 0.48 \mathrm{~mm}, 72.40 \pm 7.41 \mathrm{~mm}, 24.82 \pm 3.32$ $\mathrm{mm}$ and $50.73 \pm 4.49 \mathrm{~mm}$ respectively for South Indian males and the differences in means were significant with $\mathrm{p}$ value of $<0.001,<0.001,<0.001,<0.001,0.005$ and $<0.001$ respectively (TABLE-I). 
Upadhyay Sachin et al; Saudi J Oral Dent Res, Sep 2019; 4(9): 670-673

Table-I: Comparison of cephalometric parameters between himachali and south indian males

\begin{tabular}{|l|l|l|l|l|l|l|}
\hline & HIMACHALI MALES & \multicolumn{2}{l|}{ SOUTH INDIAN VALUE MALES } & T VALUE & p VALUE \\
\hline & Mean & S.D. & Mean & S.D. & \\
\hline Upper lip length & 20.738 & 2.5248 & 22.33 & 3.57 & 4.459 \\
\hline Interlabial gap & 1.426 & .8236 & 0.15 & 0.48 & $<0.001^{* *}$ \\
\hline Upper incisor exp. Relaxed lip & 3.006 & 1.39777 & 0.15 & 0.48 & 10.955 & $<.001 * *$ \\
\hline Lower 1/3 height & 69.200 & 5.1138 & 72.40 & 7.41 & 14.448 & $<0.001^{* *}$ \\
\hline Maxillary height & 23.744 & 2.5729 & 24.82 & 3.32 & 4.425 & 2.957 \\
\hline Mandibular height & 40.29 & 3.7279 & 50.73 & 4.49 & $0.005 * *$ \\
\hline
\end{tabular}

Statistically significant value at $* \mathrm{p} \leq 0.05, * * \mathrm{p} \leq 0.01$ and $* * * \mathrm{p} \leq 0.001$

\section{DISCUSSION}

The perception of beauty is different for different people. There are no rules governing why a face is beautiful. As professionals have increased their ability to change faces, the necessity to understand what is and is not beautiful has increased [5]. Angle suggested that if teeth were placed in optimal occlusion, good facial harmony would result [2]. The facial skeleton and its overlying soft tissue determine facial harmony and balance. It is the structure of the overlying soft tissues and their relative proportions that provide the visual impact of the face [1].

The primary goal of treatment becomes soft tissue harmony and balance, not Angle's ideal occlusion. Keeping this in mind while planning treatment is very important [6].

The Soft Tissue Cephalometric Analysis is a radiographic instrument that represents the clinical extension of the philosophy detailed in "Facial keys to orthodontic diagnosis and treatment planning." This cephalometric soft tissue analysis guides soft tissue examination, as do these earlier articles, but with added advantages. Because the STCA is a cephalometric analysis, profile soft tissue landmarks are easily seen, marked, and measured cephalometrically. Importantly, the midface metallic markers, for the first time, allow important soft tissues (orbital rim, cheekbone, subpupil, and alar base) to be easily seen, marked, and measured [4].

\section{The STCA has five distinct but cross-contributory elements}

- First, the system analyzes key dentoskeletal structures controlled by the orthodontist $(\mathrm{Mx} 1$ to $\mathrm{MxOP}, \mathrm{Md} 1$ to MdOP) and surgeon (MxOP to TVL). Orthodontic and surgical manipulation of the dentoskeletal factors is key to facial profile and esthetics.

- Second, it measures key soft tissue structures that affect facial appearance.

- Third, it measures important vertical soft tissue lengths and soft tissue to hard tissue relationships.

- Fourth, it measures soft tissue points relative to the TVL, thus producing absolute projection values for each point.

- Fifth, the absolute values are then related to one another to test facial harmony. Harmony numbers provide a test of facial balance within the individual's face and, importantly, are independent of the true vertical anteroposterior placement [15].

The present study was carried out in the Department of Orthodontics and Dentofacial Orthopaedics of Himachal Institute of Dental Sciences, Paonta Sahib (H.P). A sample of 50 Males who were residents of Himachal Pradesh in the age group of 18 25 years were considered for the study. The subjects were first assessed clinically, in natural head position, seated condyles, and with lips at rest. Then, facial examination (frontal/profile) was used as described by Arnett and Bergman [7] with particular emphasis on midface structures that do not show on standard cephalometric analysis. In particular, orbital rim, subpupil and alar base contours were noted to indicate anteroposterior position of the maxilla.

Small diameters silver beads of dimension 2 $\mathrm{mm}$ (approx.) were chosen for the use as metallic markers on the basis of their excellent radio - opaque properties even in small dimensions and since they are light weight they could easily applied on the face to the precise location with the help of paper tape according to Arnett et al. [4] in 1999. Next in the preparation for cephalometric radiograph, metallic markers in the form of small beads of silver were placed on the right side of the face to mark key mid face structures.

With the midface structures marked, the Natural Head Position was recorded. The subjects were asked to swallow and bite into centric occlusion. A cephalogram was obtained with subjects positioned in natural head position, seated condyle, and with lips at rest. The natural head position was recorded based on the method proposed by Cooke and Wei in the year 1988 according to which the subject tilted the head forward and backward with decreasing amplitude until a comfortable position of natural balance was achieved.

With the mirror, the subject was then requested to look into the reflection of their eyes in a mirror located $200 \mathrm{~cm}$ ahead. Special care was taken to ensure that the head was not moved when the ear posts were carefully inserted.

The digital cephalograms obtained were then traced with the help of (Nemotec) Dental Studio 2006 
software. After the cephalometric soft and hard tissue landmarks were measured on 50 facially balanced males of Himachali origin, dentoskeletal, soft tissue, vertical, projection and facial harmony norms and SDs were established. The values were obtained and statistical analysis was done with Student's t test.

The STCA integrates occlusal correction and soft tissue balance. The STCA is not meant as a standalone cephalometric analysis. It is meant to be used in combination with clinical facial examination and cephalometric treatment planning, to provide clinically relevant soft tissue information with checks and balances (between cephalometric and clinical facial findings) [4].

This study highlights the differences in facial structures of Himachali and South Indianmale population [8]. In the facial length measurements the Upper lip length, lower facial height and Mandibular height is more in South Indian males as compared to Himachali males whereas the interlabial gap is more in Himachali males as compared to soiuth Indian males.

These findings show that group specific norms are an essential prerequisite for accurate evaluation of orthodontic patients. The attainment of facial soft-tissue proportionality is one of the principal goals in the treatment of dentofacial deformities and can be achieved with properly planned and executed orthognathic surgery techniques. It would also help to evaluate the progress of treatment in various stages.

\section{CONCLUSION}

All male patients cannot be treated to one set of norms as the facial skeleton and its overlying soft tissue is different for Himachali and South Indian population. So, it is of utmost importance to maintain the facial harmony and balance of a particular population while treating a patient of that particular population.

\section{REFERENCES}

1. Burstone, C. J. (1967). Lip posture and its significance in treatment planning. American journal of orthodontics, 53(4), 262-284.

2. Spyropoulos, M. N., \& Halazonetis, D. J. (2001). Significance of the soft tissue profile on facial esthetics. American Journal of Orthodontics and Dentofacial Orthopedics, 119(5), 464-471.

3. William, R. (2013). Proffit, Henry W. Fields and David M. Sarver. Contemporary Orthodontics, 4.

4. Arnett, G. W., Jelic, J. S., Kim, J., Cummings, D. R., Beress, A., Worley Jr, C. M., ... \& Bergman, R. (1999). Soft tissue cephalometric analysis: diagnosis and treatment planning of dentofacial deformity. American Journal of Orthodontics and Dentofacial Orthopedics, 116(3), 239-253.

5. Scheideman, G. B., Bell, W. H., Legan, H. L., Finn, R. A., \& Reisch, J. S. (1980). Cephalometric analysis of dentofacial normals. American journal of orthodontics, 78(4), 404-420.

6. Charles J. Burstone. The Integumental profile. Am Journal of Orthodontics.1958; 44(1):1-25.

7. Arnett, G. W., \& Bergman, R. T. (1993). Facial keys to orthodontic diagnosis and treatment planning. Part I. American journal of orthodontics and dentofacial orthopedics, 103(4), 299-312.

8. Kalha, A. S., Latif, A., \& Govardhan, S. N. (2008). Soft-tissue cephalometric norms in a South Indian ethnic population. American journal of orthodontics and dentofacial orthopedics, 133(6), $876-881$ 